\title{
Mural Rights: \\ Establishing Standing for Communities Under American Moral Rights Laws
}

\author{
Christian Ehret *
}

\section{Introduction}

The origins of mural art have been traced back more than 30,000 years, evidenced by prehistoric images of animals found painted on the walls of the Chauvet Cave in Southern France. ${ }^{1}$ Throughout history, murals have been employed by man to tell stories and to convey artistic expression. The Ajanta Caves in Maharashtra, India, date back to the third century B.C. and contain intricate mural art depicting the Jataka stories. ${ }^{2}$ The San Bartolo murals in Guatemala were created in the first century B.C. and represent an important part of Mayan history. ${ }^{3}$ The significance of mural art still exists in society today and remains an effective way of communicating expression to a large, public audience. Public murals create accessible artistic expression for the enjoyment of all classes of people, help to define urban neighborhoods and offer aesthetic relief from blight and abandonment.

Given the recognized historical and artistic importance of public mural art, imagine the following scenario: an artist is given the opportunity to paint a mural on the side of a building to be enjoyed by the city and its visitors and to elevate the moods of passersby. The neighborhood chosen to host the artwork is undergoing redevelopment and revival, slowly recovering from an economically depressed past. Five years pass and the artwork has become a landmark of the neighborhood. Travel guides direct visitors to it; art journals, magazines and books have

* Christian Ehret is a second-year student at the University of Pittsburgh School of Law. He would like to thank Curt Gettman, the Public Art Program Manager of The Sprout Fund, for his time and insight into public art issues and policies.

1 Jean Clottes, Chauvet Cave: Heilbrunn Timeline of Art History (2002), http://www.metmuseum.org/toah/hd/chav/hd_chav.htm (last visited April 17, 2010).

2 The Jataka stories are about the Buddha's former existences as Bodhisattva. The 29 intricate Ajanta caves are considered to be a very important part of India's history. See generally, Walter M. Spink, Ajata - History and Development: The End of the Golden Age (Brill Academic Pub. 2005).

3 Robert J. Sharer, The Ancient Maya 263 (Stanford University Press, 6th ed. 2006). 
recognized the mural and perhaps it even makes an appearance in the background of a movie as a particularly identifying characteristic of the area. ${ }^{4}$ Then, with a few swipes of a paint roller, the wall is vacant. What took several weeks to plan, design and create is destroyed in mere minutes. What now? What can the artist do? What can the community do? Federal legislation gives artists the right to sue for damages with respect to their "moral rights" if there was no notice given prior to the destruction. ${ }^{5}$ Unfortunately, once the artist passes away or is unable to be located, the people enjoying the mural on a day-to-day basis have no recourse. ${ }^{6}$ State remedies vary widely between jurisdictions and pose even further problems. Establishing standing under moral rights laws for communities and community organizations is of critical importance to preserving the artistic and historical significance of public works of art and to maintaining the cultural identity of neighborhoods and towns which adopt them.

In proposing such a change in the law, the first part of this Note will examine the important role that public art plays in today's society in the contexts of urban redevelopment, local culture and the nurturing of artistic creation. Part II will explore existing legislation at both the federal and state levels which relate to "moral rights," along with examples of how these laws have been applied to outdoor mural art in the past. This Note will then address the issue of standing along with model laws already recognizing community rights including those of California, New Mexico and Massachusetts. The proposed change in law will then be examined in light of important considerations such as federal pre-emption and constitutionality. Finally, this Note will discuss the ways in which communities can preserve mural art for future generations by purchasing servitudes, physically removing the art, or in some other way reaching an agreement with property owners to avoid destruction.

Pittsburgh, Pennsylvania is used as a frame of reference throughout this Note to provide

4 Mural art compilations and guides to various urban murals are published for many major cities. See generally Janet Braun-Reinitz \& Jane Weissman, On the Wall: Four Decades of Community Murals in New York City (University Press of Mississippi 2009); Mary Gray, A Guide to Community Murals (University of Chicago Press 2001).

517 U.S.C. § 106A(a) (2006); 17 U.S.C. § 113(d) (2006).

6 See 17 U.S.C. $\S 106$ A(b) (2006). 
realistic examples of the effect moral rights laws can have upon society. By examining mural art in Pittsburgh, the importance of establishing standing for communities will become clear. Pittsburgh serves as an ideal backdrop for such a discussion because of its rich artistic presence, ${ }^{7}$ current revitalization efforts in the East End, and the existence of many varied, distinctive neighborhoods, each having their own unique identity and culture. ${ }^{8}$

\section{Urban Redevelopment and the Importance of Public Art}

Traditionally, the concept of "public art" implied that the work is ordered and paid for by the State and becomes the property of the State. ${ }^{9}$ However, this definition no longer reflects how society currently interprets the notion of public art. ${ }^{10}$ In modern times, the concept of public art refers to works that are accessible to the public whether or not they are commissioned by public or private entities. ${ }^{11}$

Public murals offer aesthetic pleasure in place of, or at least amongst, blight, brings members of communities together and adds to the unique cultural identity of various neighborhoods. ${ }^{12}$ Art and other cultural attractions have been used throughout the world to

7 An example of Pittsburgh's significance as an art-centric city is the Warhol Museum on the North Side of Pittsburgh. The Warhol is the largest museum dedicated to a single artist in the United States. Carol Vogel, Warhol Museum Head Announces Resignation, N.Y. Times, Feb. 7, 1995. Available at http://www.nytimes.com/1995/02/07/arts/warhol-museum-head-announces-resignation.html.

8 Michele Margittai, Insiders' Guide to Pittsburgh 323 (Insiders' Guide, 4th ed. 2008).

9 Urban Regeneration: A Challenge for Public Art 20 (Universidad de Barcelona 1997).

$10 \mathrm{Id}$. (Defining public art as a type of art "whose destiny is the entirety of non specialized citizens").

11 See, e.g., Newport News Public Art Foundation, What Is Public Art?, http://nnpaf.org/what_is_art.html (last visited April 17, 2010) ("In simple terms, public art is any work of art or design that is created by an artist specifically to be sited in a public space"); City of St. Catharines, Definition of Public Art, http://www.stcatharines.ca/recreation/resources/Definition\%20of\%20Public\%20Art.pdf (last visited April 17, 2010) ("original works of art in any artistic medium...for temporary or permanent placement in outdoor or indoor settings [that are] accessible to all members of the public and...aims to enrich the community by evoking meaning in the public realm").

12 See, e.g., The Sprout Fund, Sprout Public Art, http://www.sproutfund.org/publicart/ (last visited April 17, 2010). (explaining that the Sprout Public Art program "encourages dialogue on public art between the community and the artist, contributes to community and neighborhood development and raises awareness about the important role that local artists can have in shaping communities"); Riverside Arts Council, Private Building Mural Program Guidelines, http://www.riversideca.gov/arts/pdf/Private-Building-Mural-Program-Guidlines.pdf (last visited April 17, 2010) ("Mural projects are an investment in cultural capital that goes far beyond tourism, 
revitalize urban communities by taking advantage of low cost, unused property and attracting positive attention from outsiders. The existence of such works allows artistic expression to leave the confines of the traditional gallery or museum and become accessible to everyone. The commission of public art is also a great way to support and invigorate local artistic communities by providing an outlet and audience for artists. Public works of art serve as landmarks and symbols of communities and also serve as a reminder of difficulties once faced during the pursuit forward. ${ }^{13}$ When these works of art become integrated into neighborhoods, the hosting communities develop a strong interest in preserving them.

In redevelopment projects in the East End of Pittsburgh, the artistic community has been vital in attracting people and businesses. Along the Penn Avenue corridor, running through East Liberty, Friendship, Garfield, Bloomfield, Lawrenceville and Polish Hill, many cultural attractions have arisen out of scattered blight and economic depression. Various galleries, venues and eateries are continually attracted to the area along with artists and public interest organizations..$^{14}$ One organization, the Penn Ave Arts Initiative, addresses the high abandonment rate in the corridor by working to develop it into a "thriving arts and business destination."15 The organization restores and builds properties as studios, storefronts and housing. Along with the influx of artists to the area came The Sprout Fund, headquartered along Penn Avenue in Garfield, which has sponsored over 50 community murals since 2003 through a successful public art initiative. ${ }^{16}$ The Sprout program matches artists with communities and engages residents in the process of choosing and creating the murals. ${ }^{17}$ These public works of art are painted directly on

improved aesthetics, increased business traffic and building occupancy, and eradication of blight. Murals are an investment in a city's unique identity and its cultural cohesiveness, and contribute to its public art").

13 See Cort v. St. Paul Fire and Marine Ins. Cos., 311 F.3d 979, 982 (9th Cir. 2002) (noting that the "Lilli Ann" mural at issue had become a "familiar landmark" over a decade following its creation).

14 Galleries include Pittsburgh Glass Works, The Irma Freeman Center for the Imagination, Garfield Artworks, The Clay Penn and others.

15 Penn Ave Arts Initiative Home Page, http://friendship-pgh.org/paai/ (last visited April 17, 2010).

16 Sprout Public Art, Program Brochure \& Application (2009) (In addition to the public art program, the Sprout Fund has a Seed Award program which awards funding to community-based projects).

17 Interview with Curt Gettman, Public Art Program Manager, The Sprout Fund, in Pittsburgh, Pa. (November 2, 2009). 
the exterior walls of privately owned buildings throughout Pittsburgh.

\section{Moral Rights Protection in Mural Art}

Most legislation addressing the preservation of art is rooted in the concept of "droit moral": the rights of artists to maintain the integrity of their works. The Visual Artists Rights Act (VARA) ${ }^{18}$ is an attempt to recognize these intangible rights of integrity that have been long acknowledged in Europe and elsewhere. ${ }^{19}$ Congress' passage of VARA in 1990 was an attempt to acknowledge the rights recognized by the Berne Convention that courts were generally not willing to recognize as part of the common law. ${ }^{20}$ However, some federal courts recognized the importance of artists' rights even before VARA or related state statutes were passed and went so far as to find European-like moral rights grounded in novel unfair competition, copyright and economic theories. ${ }^{21}$ Prior to the passage of VARA, various states passed legislation that recognized moral rights. California led the movement by passing the California Art Preservation

Act in $1979 .{ }^{22}$ New York followed suit with the passage of the Artists' Authorship Rights Act in

1817 U.S.C. § 106A (2006); 17 U.S.C. § 113(d) (2006).

19 Martin A. Roeder, The Doctrine of Moral Right: A Study in the Law of Artists, Authors and Creators, 53 Harv. L. Rev. 554, 555 (1940) (Moral rights were first recognized in French courts and date back to the early nineteenth century).

20 See, e.g., Vargas v. Esquire, Inc., 164 F.2d 522, 526 (7th Cir. 1947) (declining to recognize moral rights).

21 E.g.., Gilliam v. American Broad. Cos., 538 F.2d 14, 24 (2d Cir. 1976) (“American copyright law, as presently written, does not recognize moral rights or provide a cause of action for their violation, since the law seeks to vindicate the economic, rather than the personal, rights of authors. Nevertheless, the economic incentive for artistic and intellectual creation that serves as the foundation for American copyright law [citations omitted] cannot be reconciled with the inability of artists to obtain relief for mutilation or misrepresentation of their work"); Prouty v. Nat'l Broad. Co., 26 F. Supp. 265, 266 (D.C. Mass. 1939) (finding that the misappropriation of a character in skits negatively affected the complainant's "high reputation as an author").

22 CAL. Civ. Code $\S 987-989$ (West 2006). 
$1983 .{ }^{23}$ Connecticut, ${ }^{24}$ Louisiana, ${ }^{25}$ Maine,${ }^{26}$ Massachusetts, ${ }^{27}$ Nevada,${ }^{28}$ New Jersey, ${ }^{29}$ New

Mexico, ${ }^{30}$ Pennsylvania ${ }^{31}$ and Rhode Island ${ }^{32}$ subsequently enacted legislation recognizing these rights.

Among other provisions, ${ }^{33}$ VARA provides rights for artists to "prevent any intentional distortion, mutilation, or other modification" to their works of "visual art" that would damage their honor or reputation. The statute additionally allows artists to prevent "destruction of a work of recognized stature" resulting from intentional or grossly negligent conduct. ${ }^{34}$ Similar to VARA, Pennsylvania's Fine Arts Preservation Act prevents the "mutilation, alteration or destruction of a work of fine art."35

VARA's requirement that a work be "visual art" will largely be satisfied by most murals. ${ }^{36}$ Excluded from the definition of "visual art" are works for hire, ${ }^{37}$ works not subject to copyright protection, and specific items including maps, packaging materials and works of which more

23 N.Y. Arts \& Cult. Aff. Law $§ 14.03$ (West 2006).

24 Conn. Gen. Stat. Ann. § 42-116s -116t (West 2006).

25 L.A. Rev. Stat. Ann. §§ 51:2151-2156 (West 2006).

26 Me. Rev. Stat. Ann. tit. 27, § 303 (2006).

27 Mass. Gen. Laws Ann. ch. 231, § 85S (West 2006).

28 Nev. Rev. Stat. Ann. § 587.720-760 (West 2006).

29 N.J. Stat. Ann. § 2A:24A-1 to -8 (West 2006).

30 N.M. Stat. Ann. § 13-4B-1 to -3 (West 2006).

3173 PA. Cons. Stat. Ann. § 2101-2110 (2009).

32 R.I. Gen. Laws $\S 5-62-2$ to -6 (2006).

33 While not at issue in the context of this discussion, VARA also provides artists with the right to claim authorship of their visual works, the right to prevent the use of their name as the author of any visual work which they did not create or in the event of a "distortion, mutilation, or other modification" which would be prejudicial to the artist's honor or reputation. See 17 U.S.C. § 106A(a) (2006).

3417 U.S.C. $\S 106 \mathrm{~A}(\mathrm{a})(3)(\mathrm{B})(2006)$.

3573 Pa. Cons. Stat. § 2104 (2009).

36 Murals will largely meet the statutory requirement that they be "visual art" because they are paintings that generally exist in a single copy. See 17 U.S.C. $§ 101$ (2006) (defining visual art as “(1) a painting, drawing, print or sculpture, existing in a single copy, in a limited edition of 200 copies or fewer that are signed and consecutively numbered by the author, or, in the case of a sculpture, in multiple cast, carved, or fabricated sculptures of 200 or fewer that are consecutively numbered by the author and bear the signature or other identifying mark of the author; (2) or a still photographic image produced for exhibition purposes only, existing in a single copy that is signed by the author, or in a limited edition of 200 copies or fewer that are signed and consecutively numbered by the author").

37 To determine what is considered a "work for hire," the factors from Commun. for Non-Violence v. Reid,490 U.S. 730 (1989) should be analyzed. 
than 200 copies have been made. ${ }^{38}$ VARA's "work of stature" requirement only applies when damage or alteration to an artists work is not "prejudicial to his or her honor or reputation," otherwise any work of visual art should be sufficient. ${ }^{39}$ Murals will generally satisfy legislative requirements that they be "fine art" or a "work of stature," as such terminology is broadly interpreted by courts. ${ }^{40}$ The Pennsylvania law defines a a work of "fine art" for purposes of the statute as "an original work of visual or graphic art of recognized quality created using any medium...[including], but not...limited to, a painting, drawing or sculpture." ${ }^{41}$

The protections against mutilation and destruction under VARA and various state statutes are limited when the work has been somehow incorporated into a building. ${ }^{42}$ These provisions must be examined carefully when dealing with mural art, as a finding of incorporation may result in less protection for the artist or others. Works incorporated into buildings, like murals painted directly on exterior walls, are not subject to protection under VARA if the removal of the work would cause damage to the work and if the "author consented to the installation of the work in the building" before the effective date of the act or agreed in writing that the work may be subject to damage through removal on or after the effective date of the act. ${ }^{43}$ The artist's rights in an incorporated work will also not extend to instances where the work is removable without subjecting it to "destruction, distortion, mutilation, or other modification" and the building owner makes a "diligent, good faith attempt without success to notify the author" of the intended removal or alteration, or if the author receives such notice in writing and fails to either "remove the work or...pay for its removal" within 90 days of said notice. ${ }^{44}$ The diligence requirement will be satisfied if notice is sent via registered mail to the most recent address of the author recorded

3817 U.S.C. $\$ 101(2006)$.

3917 U.S.C. $\S 106 \mathrm{~A}(\mathrm{a})(2)(2006)$.

40 See, e.g., Hanrahan v. Ramirez, No. 2:97-CV-7470, 1998 WL 34369997, at *1-8, *4 (C.D. Cal. 1998) (Finding that a drug and alcohol awareness mural was of a recognized stature because it was recognized in a contest and displayed in a government building as a photograph).

4173 Pa. Cons. Stat. § 2102 (2009).

42 E.g., 17 U.S.C. § 113(d)(1)(A) (2006); 73 Pa. Cons. Stat. § 2108 (2009).

4317 U.S.C. $\S 113(d)(1)(B)(2006)$.

4417 U.S.C. § 113(d)(1)(A) (2006); 17 U.S.C. § 113(d)(2)(A) (2006); 17 U.S.C. § 113 (d)(2)(B) (2006). 
with the Register of Copyrights. ${ }^{45}$

The Pennsylvania law takes a different approach by including an automatic waiver of rights provided by the act if the work "cannot be removed from a building without substantial physical defacement, mutilation, alteration or destruction of such fine art." ${ }^{\text {"46 }}$ Artists can, however, contract with building owners to reserve rights under the law in these circumstances and such an agreement will be binding on subsequent owners of the building through a statutorily-imposed servitude. ${ }^{47}$ Most mural art should be excluded from provisions regarding the inability to remove a work without causing damage because, although a difficult process, murals can generally be removed and preserved. ${ }^{48}$ Although it remains unclear if the Pennsylvania statute and other state laws are completely pre-empted by VARA during the life of the artist, ${ }^{49}$ the state laws will govern after the artist's death for as long as specified. ${ }^{50}$ The Pennsylvania law recognizes moral rights for fifty years following the artist's death, actionable by the artist's heir or legal representative. ${ }^{51}$

The California law is similar to the Pennsylvania law in that it requires a building owner to make diligent efforts to notify the artist's heir, legatee or personal representative before altering a "work of fine art which is a part of the building but which can be removed from the building without substantial harm." ${ }^{52}$ Also like the Pennsylvania law, the rights are deemed

$45 \mathrm{Id}$.

4673 Pa. Cons. STat. § 2108 (2009).

$47 \mathrm{Id}$.

48 Pl.'s Supplemental Declaration of Nathan Zakheim in Support of Prelim. Inj. at 2:23, Campusano v. Cort, (No. C98-3001-MJJ) (N.D. Cal. 1998), available at http://www.oliversabec.com/media/pleadings_pdffiles/lilliann/Lilliann4.pdf (introducing into evidence the fact that a mural painted directly on the exterior surface of a building could be removed for purposes of the act).

49 William F. Patry, Patry on Copyright $§ 1: 91$ (West 2009) (“[I]t is unclear whether [state laws] are preempted during the author's life"). See Bates v. Dow Agrosciences LLC, 544 U.S. 431, 449 (2005) (holding that when an express pre-emption provision has plausible alternative interpretations, courts have a "duty to accept the reading that disfavors pre-emption").

5017 U.S.C. § 301(f)(2) (2006) (Stating that the VARA pre-emption provision of $\S 301$ shall not limit rights or remedies under State laws "with respect to...activities violating legal or equitable rights which extend beyond the life of the author.").

5173 Pa. Cons. Stat. § 2107 (2009) (Stating that rights under the Pennsylvania Fine Arts Preservation Act shall exist in the artist, heir or legal representative "until the end of the 50th year following the artist's death.").

52 CAL. Civ. Code $\S 987$ (West 2006). 
waived in the event that the work cannot be removed without such harm, unless the statutory rights are expressly agreed upon by the owner of the building, in which case the agreement shall bind subsequent owners. ${ }^{53}$

A model law should abandon provisions regarding works incorporated into buildings all together as such provisions fail to consider a potential willingness of artists or communities to purchase a servitude in the property or in some other way negotiate with building owners. Building owners should not determine whether or not a work is removable, as only professionals who are familiar with the latest technologies in art preservation are in a position to make such a decision. Additionally, the fact that a work of art cannot be removed without causing substantial harm to the work should be for artists or communities to disprove through failed attempts to do so. As is already provided for by the relevant statutes, if the party bringing a claim cannot remove the work within a certain period of time, the rights should lapse. The inclusion of an automatic expiration provides enough protection for the property owner so that provisions lessening protection for works incorporated into a building are not necessary.

The Sprout Fund addresses many potential issues of future destruction of their commissioned mural art in the contract that they require building owners to sign. Building owners who elect to participate in the program, often spurred by community encouragement, contract with The Sprout Fund to keep the murals permanently on their property. ${ }^{54}$ Owners additionally agree that they do not intend to sell or destroy the property and that, if they do sell it in the future, they will exercise their best efforts to transfer the agreement to any downstream owners. ${ }^{55}$ This "best efforts" requirement to regulate the transfer of the agreement to subsequent purchasers does not amount to a fully restrictive servitude on the property, likely due to a desire to not discourage building owners from signing and participating. Even so, this clause is sometimes modified by property owners when they sign the Sprout contract, the modification

$53 \mathrm{Id}$.

54 Interview with Curt Gettman, supra note 17, at 4.

$55 \mathrm{Id}$. 
usually stipulating that the agreement will in no way conflict with future efforts to sell the property. ${ }^{56}$ This is a compromise that artists and organizations like The Sprout Fund must make in order for building owners to allow their exterior walls to be used as canvases. As property changes hands in the future, either through sale or through the original owners' heirs, such agreements may be challenged. Luckily, The Sprout Fund has yet to run into any such problems and has even been successful in having subsequent purchasers sign new agreements with the organization after acquiring the properties. ${ }^{57}$ Possible consideration issues aside, such willingness of purchasers to enter into new agreements reflects the cultural value and public embrace of the murals.

Although the amount of litigation under moral rights legislation has been minimal, the laws have been used successfully to provide remedies for destroyed mural work in the past. However, most mural cases brought under VARA or similar statutes have settled, leaving little in terms of judicial interpretation and application. In 2008, the U.S. Government and other defendants agreed to pay a $\$ 1.1$ million settlement for painting over a six-story mural by artist Kent Twitchell. ${ }^{58}$ In March of that year, artist Salvador Torres reached an undisclosed settlement for the destruction of a San Diego mural without notice. ${ }^{59}$ The Torres mural was painted in 2005 with the consent of the building owner and the support of community members, nonprofit organizations and local businesses. The colorful mural was painted over that same year with a dark paint, forever destroying the work. ${ }^{60}$

The power of VARA was exercised by a federal district court in 1998 by awarding a muralist a $\$ 30,000$ settlement and injunctive relief against a building's lessee who had painted over the artist's work of art. ${ }^{61}$ The mural was commissioned by the Ventura County Department

$56 I d$.

$57 \mathrm{Id}$.

58 Diane Haithman, Artist Kent Twitchell Settles Suit Over Disappearing Mural. Los Angeles Times, May 1, 2008, available at $\mathrm{http} / /$ www.latimes.com/entertainment/news/arts/la-et-twitchell1-2008may01,0,765959.story.

59 Pat Broderick, Artist, Building Owners Settle Case of Painted-Over Mural, DaiLy Journal (March 21, 2008),

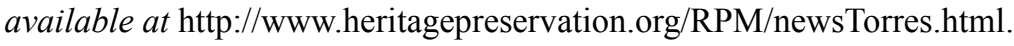
$60 \mathrm{Id}$.

61 Hanrahan v. Ramirez, supra note 40, at *7 (Although the muralist was denied punitive damages from the court, 
of Alcohol and Drug Programs to convey an anti-drug and alcohol message to local youth. ${ }^{62}$ The court found it indisputable that VARA applied to the mural, finding liability on behalf of the building owner, who consented to the mural, and two lessees who painted over one-third of the mural.

One of the most well-known and publicized mural cases involved the so-called "Lilli Ann mural," painted on the side of a former Lilli Ann Corporation factory building in the Mission District of San Francisco. ${ }^{63}$ The artists brought an action under VARA and the California statute seeking injunctive relief and $\$ 500,000$ in damages after the mural was painted over with an opaque sealant. ${ }^{64}$ The City of San Francisco, which had paid $\$ 40,000$ for the mural's creation, intervened as plaintiffs but the parties eventually settled for $\$ 200,000$ in exchange for the artists' relinquishment of control over the work. ${ }^{65}$

\section{III.The Issue of Standing}

Although moral rights laws were enacted for purposes congruent with communal and societal interests in art and culture, such interests remain largely unaddressed. When VARA was considered in the United States House of Representatives, a significant rationale for its enactment was the need to preserve important works of art that eventually become "an invaluable part of American culture." 66 Accordingly, a New York federal court found that VARA was "specifically designed to further the public interest" in works of art. ${ }^{67}$ However, VARA only recognizes the right of the original artists to seek relief, even under the provision that protects

half of the award was to cover the cost of restoring the work and the other half to compensate the artist for emotional distress and damage to her reputation in the community).

$62 \mathrm{Id}$. at 1 (Ironically or not, the mural was painted on the exterior wall of a liquor store, with the store owner's consent).

63 Cort, supra note 13, at 982 (dealing with a post-settlement insurance dispute arising out of the Campusano v. Cort litigation).

64 Id.

$65 \mathrm{Id}$.

66101 Cong. Rec. H2690 (daily ed. June 13, 1990) (statement of Rep. Williams).

67 Carter v. Helmsley-Spear, 861 F. Supp. 303, 328 (S.D.N.Y. 1994). 
works of "recognized stature" regardless of damage to the artists' reputation. ${ }^{68}$ It would be erroneous to assume that only an artist has moral rights in public works of art because the very nature of public art dictates a societal interest. Communities which have adopted public murals, including local businesses, organizations and school groups, are often involved in the creation of murals and thus have an interest in preservation that may even exceed that of the artists. ${ }^{69}$ With the public interest in the preservation of art being a central policy rationale to moral rights legislation, standing under the laws should be extended to community members and organizations in a limited fashion when the art at issue is public. In this way, moral rights in outdoor murals and other forms of public art can be shared with the communities in which they exist.

The Sprout Fund's public art initiative prides itself on involving the Pittsburgh communities that serve as hosts to their commissioned mural works in the creative process, including the choice of art and artist. ${ }^{70}$ The program is rooted in encouraging dialogue between communities and addressing the need to support local artists and develop personal investments and leadership in neighborhoods. ${ }^{71}$ The Sprout Fund accepts applications from community organizations or individuals that wish to participate in the public art program. ${ }^{72}$ Ideally, the intended destruction of murals commissioned by the Sprout Fund would be actionable by the artist, The Sprout Fund, the City of Pittsburgh, and by other community groups with a legitimate interest in the preservation of local art and culture.

Unfortunately, VARA and most state statutes only provide standing for the artists that create the work. While artists certainly have an interest in maintaining the integrity of their works, the creation of mural art is inherently a gift to the public. VARA prohibits artists from

6817 U.S.C. $\S 106 \mathrm{~A}(\mathrm{a})$ (2006).

69 See Hanrahan, supra note 40, at*1 (noting that the liquor store mural, commissioned by the Ventura County Department of Alcohol and Drug Programs, was completed by the artist "with the assistance of some 300 members of the community" including local youth).

70 Interview with Curt Gettman, supra note 17, at 9.

71 Sprout Public Art, http://www.sproutfund.org/publicart (last visited April 17, 2010).

72 Sprout Public Art, Program Overview, http://www.sproutfund.org/publicart/overview (last visited April 17, 2010). 
transferring, sharing or bestowing their rights, although it does allow for the rights to be waived. ${ }^{73}$ The Pennsylvania law and those of other states extends artists' rights to their heirs or legal representatives after death. ${ }^{74}$

The California statute, the earliest example of moral rights legislation in America, expressly addresses this issue, recognizing "a public interest in preserving the integrity of cultural and artistic creations." ${ }^{75}$ The California law gives standing to certain community organizations "acting in the public interest" to obtain injunctive relief against the intentional "physical defacement, mutilation, alteration, or destruction of a work of fine art.", The organizations qualified for such rights are public or private entities or associations that have been in existence for at least three years and have a "major purpose" directed at presenting works of art to the public or promoting the interests of the art or artists. ${ }^{77}$ If the heir, legatee or representative fails to respond within 30 days of the notice requirements set forth in the statute, the owner is required to provide written notice in a newspaper generally circulated in the area where the art is located. ${ }^{78}$ From the published notice, organizations would then have 30 days to respond.

Statutes for Massachusetts and New Mexico also provide standing for "bona fide union[s] or other artists' organization[s]" with the written consent of the artist. ${ }^{79}$ Aside from this express agreement requirement, these states provide even more protection than the California statute in that such organizations are not limited to injunctive relief and can seek actual damages for the destruction of a work. Additionally, these states grant the state attorney general standing to assert the rights of a deceased artist to seek injunctive relief when the art in question is on the

7317 U.S.C. $\S 106 \mathrm{~A}(\mathrm{e})(2006)$.

7473 Pa. Cons. Stat. § 2105 (2009).

75 CAL. Civ. Code $\S 989$ (a) (West 2006). The statutes for Massachusetts and New Mexico also make such a declaration.

76 Cal. Civ. Code $\S 989$ (c) (West 2006); Cal. Civ. Code $\S 989$ (e)(1) (West 2006).

77 Cal. Civ. Code $\S 989$ (a)(2) (West 2006).

78 CAL. CIv. Code $\S 989$ (e)(2)(A) (the published notice requirement can be satisfied concurrently with the notice requirement to the artist's heir, legatee or personal representative).

79 Mass. Gen. Laws Ann. ch. 231, § 85S(e) (West 2006); N.M. Stat. Ann. § 13-4B-3 (West 2006). 
"exterior of a public owned building, or in an interior area of a public building." $\$ 0$

Rights under VARA can be shared among joint authors, with rights lasting for the life of the longest-surviving author. ${ }^{81}$ Communities should be treated similarly to joint authors when it comes to the right to prevent destruction or mutilation of a work of public art. Under the federal statute, even an artist's estate could not exercise VARA rights even if the creator passed away mere days after the work was completed. Communities, as entities recognized by amassed residents, groups and organizations, may not be joint authors as far as the law is concerned but certainly share common interests with the artists comparable to that of a joint author.

In Pittsburgh, organizations like The Sprout Fund which commission works of public art should have the ability to at least seek injunctive relief after learning of planned destruction of a particular work. Establishing this standing could be done at the state level, as is allowed by the California, New Mexico and Massachusetts statutes, but doing so would risk pre-emption during the artist's life. By requiring public notice in a newspaper before destroying works of art exposed to the public, organizations will have the opportunity take action to preserve the works. Another solution would be to allow the rights against destruction and mutilation to be jointly shared with organizations that commission the works. Such a change in law would not require public notice, but would require specific notices to the organization that commissioned it as well as to the artists.

Changing VARA to allow for community standing may also require a change in agreements used by organizations that commission public art. Building owners should be made aware of the obligations that will arise if they intend to destroy or alter the mural by agreeing to give notice to both the artist and the organization, or to a specified organization, association or local government. Giving notice to the community is important in case the artist does not

80 Id.

81 Although joint authors share rights under VARA, a single joint author can waive the rights for all authors. See 17 U.S.C. $\$ 106 A(b)$ (2006). See also Peter K. Yu, Intellectual Property and Information Wealth: Issues and Practices in the Digital Age 102 (Praeger Publishers, Dec. 2006) (noting that the waiver allowance among joint authors may undermine the policy behind moral rights laws). 
respond or is otherwise unavailable.

\section{Potential Problems: Preemption and Unlawful Takings}

Legislative measures designed to protect works of public art and provide communities with standing must be carefully constructed so as to avoid constitutional challenges and, in the case of state laws, not run afoul of the doctrines of federal supremacy.

State remedies, while attractive, may prove to be problematic because of VARA's express pre-emption provision, which nullifies state moral rights during the life of the artist. ${ }^{82}$ Although the extent to which relevant state law provisions regarding moral rights are pre-empted by VARA remains unclear, it is important to consider this potentiality when relying on state laws to protect works of art. ${ }^{83}$ Given this express pre-emption, it is highly likely that, even if the law which governs a particular work provides for community standing, such provisions would be rendered ineffective until the artist passed away. ${ }^{84}$ Such a system would leave communities with no recourse or remedy if the artist could not be found or if the artist has no interest in preserving the art.

All state laws conferring rights upon artists are not completely pre-empted by VARA.

Aside from allowing state remedial measures extending beyond the life of the artist, an exception is provided for state historical preservation laws. ${ }^{85}$ The historical preservation exception, which

8217 U.S.C. §301(f)(1) (2006).

83 See William F. Patry, Patry on Copyright § 1:91 (West 2009) (“[I]t is unclear whether [state laws] are preempted during the author's life"). See also Bates v. Dow Agrosciences LLC, 544 U.S. 431, 449 (2005) (holding that when an express pre-emption provision has plausible alternative interpretations, courts have a "duty to accept the reading that disfavors pre-emption").

84 See Board of Managers of Soho Int'l Arts Condo. v. City of New York, No. 01 Civ.1226 DAB, 2003 WL $21403333, * 1-27$, at *11-14 (S.D.N.Y. 2003) (finding that the rights of integrity granted by the New York statute are "equivalent" to those granted by VARA and thus pre-empt the state rights, even though the state statute grants rights that are more protective than those granted by VARA. The court broadly ruled that "any state statute enacted to protect artists' moral rights, specifically those of attribution or integrity (and even those which afford greater protections to artists), would be pre-empted by VARA.”).

8517 U.S.C. § 301(b)(1) (2006) ("Nothing in this title annuls or limits any rights or remedies under [State law] with respect to...State and local landmarks, historic preservation, zoning, or building codes, relating to architectural works under section 102(a)(8)"); 17 U.S.C. § 301(f)(2) (2006) ("Nothing in [the express pre-emption provision 
specifies that state laws dealing with "[s]tate and local landmarks [and] historic preservation" with respect to architectural works will not be pre-empted, might be utilized by states seeking to craft legislation that protects mural art in light of federal supremacy. While there may exist many novel arguments for such a construction, the restriction that the work be an "architectural work," as defined by copyright law, may prevent such legislation from protecting mural art. Although the architectural work limitation to this exception may not explicitly cover paintings on the exteriors of buildings, the existence of this provision shows a Congressional intent to give states deference when it comes to preserving elements of local history. ${ }^{86}$ Legislation availing itself of this exception would have to be careful to specify that certain works of art incorporated into buildings make the entire building a landmark for preservation purposes.

Legislation creating community rights in mural art - at any level of government - must be crafted to find a balance between the interests of preservation and the physical property rights of building owners. The United States Constitution guarantees that no person be deprived of property without due process of law and that private property will not be taken for public use without just compensation. ${ }^{87}$ In passing moral rights laws, legislatures surely did not intend to prioritize interests of art preservation and artistic integrity over the rights of others. ${ }^{88}$

Landowners should be encouraged to allow their properties to be used as canvases but may choose not to if the law restricts them from ever repainting their building or from selling it to others at the highest possible value. Fining building owners for painting over a mural without exercising the notice requirements of a moral rights law could prove to be an infringement of property rights, although a court has not yet ruled on this issue. Requiring additional notices to

for VARA] annuls or limits any rights or remedies under [State law] with respect to...activities violating legal or equitable rights which extend beyond the life of the author").

86 There exist a wide variety of historical preservation laws at both the state and federal level. See e.g., 37 PA. Cons. Stat. $\S \S 501-512$ (2009) (contains provisions regarding Pennsylvania state protection of historic properties).

87 U.S. Const. amend. V, cl. 4.

88 Carter v. Helmsley-Spear, Inc., 71 F.3d 77, 80 (2d Cir. 1995) (reversing injunctive relief granted to plaintffs because Congress, in passing VARA, "did not mandate the preservation of art at all costs and without due regard for the rights of others"). 
community organizations or to the public may only complicate this constitutional uncertainty.

The constitutionality of VARA was challenged under the Takings Clause, the First Amendment and for reasons of vagueness in a case brought against the Hollywood Art and Culture Center, although the parties reached a settlement prior to any judicial determination. In that case, the U.S. government intervened to defend the statute's constitutionality, claiming that VARA was flexible enough to survive the challenges. ${ }^{89}$ The Supreme Court has held that landmark preservation laws even more restrictive than those of moral rights laws are permissible under the Takings Clause. ${ }^{90}$ Merely having to provide notice to the community and a reasonable time to allow the work to be preserved is significantly less restrictive than what the Court has already deemed to be acceptable. ${ }^{91}$

\section{The Decision to Preserve}

Once notice of destruction is given to community organizations, a decision must be made about if and how to preserve the work of art. There are two basic routes to take: preserving the art, as is, on the original wall, and removing the work of art for display elsewhere. An equitable servitude can be placed on the property to ensure a work's preservation despite transfer of ownership. Respect for property rights and unconstitutional takings mandates that such servitudes are merely optional and that "just compensation" be paid in exchange for the restrictions. The Sprout Fund agrees to maintain the murals that they commission, possibly serving as consideration for a property owner's consent, which may be enough consideration for a restrictive servitude agreement. Financial compensation is also a possibility, as is statesponsored beneficial tax treatment. By placing reasonable time limits on servitudes and

89 See generally Memorandum of Law of the United States in Support of the Constitutionality of the Visual Artists Rights Act of 1990 and in Response to Defendant's Motion for Final Summary Judgment, available at http://www.oliversabec.com/media/pleadings_pdffiles/vara/4Vara-NE.pdf.

90 Penn Cent. Transp. v. City of New York, 438 U.S. 104, 133 (1978).

91 This is not to say that the interests advanced by landmark preservation laws at issue in Penn Cent. Transp. v. City of New York are equivalent to those advanced by moral rights laws. 
providing consideration, communities could preserve murals on original walls without the expense of removing them. Servitudes are also an option if moral rights for communities cannot be obtained through legislation, as community groups and local governments can negotiate with building owners to purchase these rights at the offset of the creation of the work.

An argument could be made that many murals are not meant to last forever, especially those painted on the exterior walls of buildings. Murals installed with wheat paste have a lifespan of approximately two years. ${ }^{92}$ Certain paints won't last much longer, especially in the climate of Pittsburgh. The Sprout Fund uses long-lasting paints and a protective clear-coat, but that too will erode over time. ${ }^{93}$ Despite such physical limitations, communities should have the opportunity to preserve pieces of art for as long as possible if they choose to do so. VARA does not require complete permanence with physical property owners, but rather only stipulates that a possessor of moral rights be notified before any detrimental action is taken. Once notice is received, murals can be removed, even those painted directly on walls. In a 1998 pleading under VARA, an art restoration expert testified that he had successfully removed twenty acrylic murals that were painted directly on exterior walls ${ }^{94}$. Since "most murals can be safely removed and redisplayed," $" 95$ it is crucial that the artists as well as the communities which adopt public art receive ample notification prior to the destruction of a mural so they can decide whether or not to take actions to preserve it.

\section{Conclusion}

The East End neighborhoods of Pittsburgh are slowly becoming the new cultural district

92 Art Commission Minutes of the Meeting of September 30 Beginning at 2:00 PM, Pittsburgh Arts Commission 2 (2009), available at http://www.city.pittsburgh.pa.us/cp/assets/art_commission/2009/09-30-09_minutes.pdf. 93 Interview with Curt Gettman, supra note 17, at 9.

94 Pl.'s Supplemental Declaration of Nathan Zakheim in Support of Prelim. Inj. at 2:10-12, Campusano v. Cort, (No. C98-3001-MJJ) (N.D. Cal. 1998), available at http://www.oliversabec.com/media/pleadings_pdffiles/lilliann/Lilliann4.pdf.

$95 \mathrm{Id}$. at 2:23. 
of Pittsburgh, perhaps to the chagrin of 6th Street business owners, and have developed an interest in preserving the steps of their progress. Community organizations and residents are in the best position to exercise rights to public art because of the difficulty that building owners may face in locating an artist to provide the requisite notice. Simple modifications of already existing laws could close a legislative gap that risks the loss of many great works of art. The communities will always be present, to enjoy public art and to preserve it as part of their cultural identity. 